\title{
Stanisław Dubisz, \\ Język - historia - kultura (wykłady, studia, analizy) \\ Warszawa 2002, s. 300
}

Chociaż autor expressis verbis $\mathrm{w}$ żadnym miejscu nie nazywa swej książki podręcznikiem akademickim, to dla doświadczonego czytelnika nie ulega wątpliwości, że do takiego miana omawiany zbiór studiów pretenduje. Za taką oceną charakteru książki przemawiają względy czysto formalne, ale i jej merytoryczna zawartość

Już w podtytule na pierwszy plan wysuwają się "wykłady", dopiero na dalszych miejscach figurują "analizy" i "studia” w mniej jednoznaczny sposób kojarzące się nauczaniem. Nie sposób nie dostrzec również tego, że w przedmowie autor kładzie nacisk na dydaktyczne okoliczności powstania pracy, widząc w swoich rozważaniach przede wszystkim osobisty komentarz do - prowadzonych przez ponad trzydzieści lat - zajęć $z$ diachronicznego językoznawstwa polonistycznego.

To dydaktyczne nacechowanie każe nam przyjrzeć się analizowanemu zbiorowi z perspektywy innych syntetycznych opracowań zagadnienia, zwłaszcza powszechnie znanych i wykorzystywanych w dydaktyce podręczników akademickich oraz ujęć do takiego potraktowania aspirujących. Mam tu na myśli przede wszystkim monumentalną i wielokrotnie wznawianą, także ostatnio, Historię języka polskiego Zenona Klemensiewicza (1999), skrypt Szkice $z$ dziejów polskiego języka literackiego Haliny Rybickiej-Nowackiej (1990) oraz nowsze syntezy, mianowicie: lapidarną i niemal popularną wersję Bogdana Walczaka Zarys dziejów języka polskiego (1999), a także historiozoficzne i metodologiczne Wprowadzenie do historii języka polskiego (2000) Stanisława Borawskiego.

Już pierwszy rzut oka na książkę S.Dubisza pozwala na zasadniczą konstatację - omawiany zbiór studiów, choć z natury rzeczy uwzględnia problematykę ogólną i szereg kwestii szczegółowych, bez których żadne z wymienionych ujęć obejść się nie mogło, w żadnym wypadku 
nie powiela osiągnięć poprzedników. Wręcz przeciwnie, "Język-historia-kultura" to książka pod wieloma względami nowatorska.

Nie kłócąc się z tradycją opracowań tego typu, rozpoczyna S. Dubisz nową tradycję pisania historii języka polskiego, której nie tylko tłem, ale istotnym, może najważniejszym czynnikiem czyni składniki kultury, polską historię polityczną i gospodarczą, proces kształtowanie się polskiej państwowości, słowiańską i staropolską kulturę materialną oraz folklor i sferę wierzeń. $Z$ jednej strony czuje się tu obecność ducha $A$. Brücknera, $z$ drugiej widać wyraźne inspiracje i nawiązania do tych metod uprawiania językoznawstwa, które nie tylko każą widzieć w języku uniwersalny element kultury, ale interpretować jego fakty poprzez pryzmat kultury.

Obecność w tytule tomu poza hasłem "język”, członów „kultura” i „historia”, służy nie tylko uwydatnieniu określonego sposobu postrzegania zjawisk historycznojęzykowych, ale też usytuowaniu pracy w sekwencji, którą wyznacza dorobek wielkich poprzedników.

Praca S. Dubisza w formie jasnego i zajmującego wykładu wprowadza istotne uzupełnienia i korektury, zwłaszcza wobec nieco anachronicznego już podręcznika Z. Klemensiewicza. Część zagadnień została tu potraktowana odmiennie niż $w$ dostępnych starszych opracowaniach, inne kwestie doczekały się aktualizacji lub zostały przedstawione w szerszym kontekście. Nie brak tu wreszcie nowych, niebanalnych interpretacji faktów historycznojęzykowych oraz wyników własnych dociekań.

Omawiana praca $\mathrm{w}$ niewielkim stopniu przypomina tradycyjny kurs historii języka polskiego, jest raczej zbiorem wybranych studiów i analiz $\mathrm{z}$ tego zakresu. Jak $\mathrm{w}$ wypadku każdego wyboru nie może ona rościć sobie prawa do kompletności, niemniej jednak warto podkreślić, że nie pominięto $w$ niej żadnej kwestii naprawdę istotnej.

Książka składa się z dziesięciu rozdziałów, jednak w jej ramach można wyróżnić trzy, cztery wyraźnie odrębne wątki merytoryczne.

Pierwsze dwie części książki stanowią swoistą całość, można by je uznać za rodzaj wprowadzenia do historii języka jako autonomicznej dyscypliny językoznawczej wyraźnie odrębnej od gramatyki historycznej, dysponującej odpowiednim aparatem metodologicznym. Poza przedstawieniem podstawowych pojęć, źródeł i metod historii języka 
autor koncentruje się na, kluczowym dla diachronicznych dziedzin językoznawstwa, zagadnieniu periodyzacji dziejów języka.

W kolejnych trzech rozdziałach historia języka polskiego została ukazana z perspektywy słownikowej na zasadzie powiązania etapów rozwoju polskiej leksyki $\mathrm{z}$ najważniejszymi wydarzeniami historycznymi, zwłaszcza zagadnieniem powstania i rozwoju polskiej państwowości, systemem wierzeń oraz kulturą duchową i materialną dawnych Słowian i Polaków.

„Filologiczną" część studiów tworzą rozdziały poświęcone piśmiennictwu staropolskiemu, zwłaszcza liryce religijnej. Książkę zamyka rozdział traktujący o roli łaciny w historii polszczyzny. Samodzielną całość stanowi obszerny fragment poświęcony, dyskutowanemu od wielu lat, problemowi pochodzenie polskiego języka literackiego.

Mimo różnorodności materii książka sprawia wrażenie dobrze przemyślanej i harmonijnej całości. Zwraca uwagę znakomite rozeznanie autora $w$ literaturze przedmiotu (także najnowszej) oraz odwaga $\mathrm{w}$ formułowaniu własnych sądów i opinii.

W tym dziele widać jak na dłoni, jak procentuje merytoryczne i metodyczne doświadczenie zdobyte nie tylko w trakcie wieloletniej pracy akademickiej, ale też stanowiące rezultat wielu dokonań wydawniczych autora, w tym popularnego cyklu esejów o języku Między dawnymi i nowymi laty, szkiców z zakresu historii stylu retorycznego zatytułowanych Język i polityka oraz podręczników, zwłaszcza Nauki o języku dla polonistów czy opracowanej wspólnie z Krystyną Długosz-Kurczabową Gramatyki historycznej języka polskiego (2001).

Podręcznik S. Dubisza cechują liczne walory merytoryczne i dydaktyczne. Ponieważ jednak w każdej beczce miodu nie może zabraknąć łyżki dziegciu, więc i w wypadku tej pracy nasuwają się drobne uwagi krytyczne dotyczące przede wszystkim kompozycji tomu.

Przedyskutowania, i być może uwzględnienia w następnych wydaniach, wymagałyby następujące sprawy:

1. Skoro większość przedstawionych $\mathrm{w}$ analizowanym tomie studiów dotyczy okresu staropolskiego, być może warto by było zasygnalizować zakres ujęcia w tytule lub podtytule.

2. Jednym $z$ kluczowych zagadnień rozważanych obszernie $w$ tej książce, jest periodyzacja dziejów języka. Wydaje się, że bez szkody 
dla jasności i logicznej wartości wykładu, można by tę kwestię omówić $\mathrm{w}$ obrębie jednego rozdziału.

3. Problem pochodzenia polskiego języka literackiego stanowi niejako samodzielną całość, mógłby jednak zostać włączony do pierwszej, teoretyczno-metodologicznej części opracowania. Ponadto rozdział ten kończy się zbyt nagle, przydałoby się chociaż kilka, nawet ogólniejszych uwag na temat dalszych losów literackiej polszczyzny

4. Bardzo ciekawy, ale chyba nazbyt rozbudowany i szczegółowy fragment (s. 75--87) dotyczący nazwisk mazowieckich mieszczan spowalnia narrację i czyni ten fragment mniej atrakcyjnym dla czytelnika.

5. Do rzadkości należą $\mathrm{w}$ tej książce zderzenia wątków staropolskich i współczesnych, a szkoda, gdyż - jak dowodzą tego s. 45-47 zdecydowanie uatrakcyjniają one tok wywodu i poszerzają perspektywę wydarzeń.

Oczywiście wszelkie usterki i uchybienia, czy tylko momenty wątpliwe, nie mogą przesłonić dużej wartości poznawczej i dydaktycznej całego opracowania. Książka, niosąc powiew świeżości, dobrze wkomponowuje się $\mathrm{w}$ tradycję zewnątrzjęzykowego wykładania i pisania historii języka polskiego Cały tekst jest napisany gładko i potoczyście, od stylu naukowego autor zgrabnie przechodzi do eseju, a nawet gawędy. Wykład jest interesujący dla specjalisty i przeciętnego czytelnika, tok rozumowania logiczny, jasny i przystępny, ale bez śladu trywializacji zagadnienia. 